\title{
"A natureza não aparecia nas aulas de História": lições de educação ambiental aprendidas a partir das memórias de professores de História
}

\author{
Ely Bergo de Carvalho'
}

Entender quais as representaçóes da natureza produzidas por professores e alunos é uma parte importante para uma atuação mais eficaz no processo de educaçáo ambiental. De uma forma geral, diante de conflitos socioambientais, está cada vez mais claro que não se podem ignorar os modelos de açáo e cognição dos sujeitos ou pressupô-los, como se todos compartilhassem uma racionalidade economicista (Leff, 2005).

Todavia, diferente de alguns estudos de representação social sobre o ambiente que adotam uma abordagem sincrônica (Reigota, 1995), a proposta aqui é efetuar uma abordagem diacrônica e entender o processo pelo qual a atual questão ambiental se insere nas práticas e representaçóes dos professores de História. Com tal intuito, a pesquisa partiu de entrevistas realizadas com professores(as) de História em atividade na rede pública de ensino básico da cidade de Cuiabá, Mato Grosso, Brasil. A partir do resultado obtido com tais entrevistas (Carvalho, 2012), e para ampliar a compreensão da dimensão diacrônica na mudança das representaçôes de natureza, foram realizadas entrevistas com professores aposentados que lecionaram a disciplina História na rede pública de ensino básico de Cuiabá, sendo que, dos

1 Professor adjunto de História Ambiental da Universidade Federal de Minas Gerais. E-mail: carvalho2010@yahoo.com.br 
três professores aposentados, dois deles não tinham formação em História, mas, sim, em Pedagogia, uma vez que a geração de professores que lecionaram a disciplina História, hoje aposentada na cidade, via de regra não tinha formação específica.

Por meio da metodologia da história oral, o estudo apontou para uma representação disjuntiva de natureza e história/cultura — o que já foi constatado em outros trabalhos sobre a representação de natureza entre professores (Reigota, 1995) - e para uma concepção de educação ambiental, a qual se aproxima, no limite, do que alguns autores chamam de "adestramento ambiental” (Brüger, 2004, p. 36). Todavia, também se pode perceber, na narrativa dos professores entrevistados, uma representação mais complexa de natureza. Porém, para iluminar tais questóes complexas, fazem-se necessárias, primeiro, algumas consideraçóes sobre as relaçóes entre história e natureza e entre ensino de história e educação ambiental, para que, então, se possam abordar as representaçóes de natureza e educação ambiental presentes nas narrativas dos entrevistados.

\section{História e natureza: a disjunção}

O mundo moderno é marcado pelo mecanicismo. Desde, pelo menos, a chamada Revolução Científica do século XVI, a máquina tornou-se a grande metáfora para se entender a natureza. Como afirma Morin (1999), a lógica das máquinas artificiais, as quais são incapazes do desvio, do erro, tem como pressuposto que a realidade é simples, ou seja, que ela é objetiva e contém um conjunto de leis que podem ser formalizadas e que permitiriam controlar o objeto estudado, pois possibilitariam a previsão de seu funcionamento. Mas a lógica da máquina artificial foi aplicada não apenas na relação dos seres humanos com a natureza, mas entre os próprios seres humanos. Dessa forma, tanto o Estado como a sociedade civil moderna pautam-se em esquemas da máquina artificial, baseando-se em uma racionalidade sustentada na centralização, na especialização e na hierarquia, ou seja, baseiam-se no que outros autores chamam de uma racionalidade burocrático-técnica, o que forma uma visão de mundo fundamentada na lógica da máquina artificial, ou seja, em uma racionalização. 


\section{Entende-se que racionalização}

é a construção de uma visão coerente, totalizante do universo, a partir de dados parciais, de uma visão parcial, ou de um princípio único, assim, a visão de um só aspecto das coisas (rendimento, eficácia), a explicação em função de um fator único (o econômico ou o político) (Morin, 1999, p. 155).

Com seu conceito de racionalização, Morin (1999, p. 169) lembra que "o real excede o racional". Afinal, por exemplo, uma breve incursão pela história do pensamento científico ocidental mostra os mitos sobre os quais tal visão de mundo se constrói; por exemplo, o mito de que o mundo é simples e controlável. Dessa forma, ressalta-se que tal visão totalizante, pautada em um elemento parcial, implica não a eliminação dos mitos, mas apenas a sua reelaboração e a criação de novos mitos (Diegues, 1998, p. 54). Assim, felizmente, não se está, necessariamente, condenado a uma visão de mundo racionalizadora, simplificadora e maquinica, como afirma Schama:

[... se toda a história da paisagem no Ocidente de fato não passa de uma corrida insensata rumo a um universo movido a [sic] máquina, sem a complexidade de mitos, metáforas e alegorias, no qual o árbitro absoluto do valor é a medição e não a memória, no qual nossa inventividade constitui nossa tragédia, então realmente estamos presos no mecanismo de nossa autodestruição (Schama, 1996, p.24).

Apesar de o processo de racionalização da natureza procurar transformá-la em um depósito de recursos, ela nunca foi só isso, pois, como argumenta Revel (1998), não se pode considerar que as "máquinas do poder" funcionam perfeitamente, porque em geral elas assim "funcionam", justamente porque os historiadores a entendem como máquinas e não como um conjunto de relaçôes, e "mesmo se admitir a hipótese de uma eficácia global dos aparelhos e das autoridades, falta entender inteiramente como essa eficácia foi possível, ou seja, como foram retranscritas, em contextos indefinidamente variáveis e heterogêneos, as injunçôes do poder" (Revel, 1998, p. 29). Ou, para seguir o raciocínio de Morin (1999), a lógica das máquinas artificiais não suporta a desordem, que, se por um lado é fonte de destruição, por outro, é fonte de liberdade. Como a criação pressupóe uma desordem criadora, a autoprodução permanente da sociedade não é com- 
portada pela lógica da máquina artificial. Dessa maneira, os "processos de criatividade e de invenção não são redutíveis à lógica da máquina artificial” (Morin, 1999, p. 110-111).

Além da simplificação do mundo, tal paradigma tem como uma de suas principais características a disjunção. $\mathrm{O}$ paradigma moderno foi fundado sob o princípio da redução-disjunção, o que leva à "grande disjunção natureza-cultura, objeto-sujeito” (Morin, 1999, p. 30).

Essa questão situa-se na fundação das ciências modernas:

O problema metodológico enfrentado por Descartes é o seguinte: se existe uma unidade da razão, deve haver algo que necessariamente náo seja uno e, portanto, seja divisível. Este algo é o mundo, a natureza, tornada objeto da razão. [...] A questão é simples: Como posso dominar alguma coisa da qual faço parte? A resposta é que não posso; conseqüentemente [sic], náo posso fazer parte da natureza. Se pretendo dominá-la, preciso me situar fora dela. Assim, Descartes consegue legitimar a unidade da razão às custas $[$ sic] da objetificação da natureza. [...] É na base desse dualismo que encontramos a gênese filosófica da crise ecológica moderna [...]. A natureza e a cultura passam a ser duas coisas muito distintas (Grün, 2000, p. 34-35).

Por mais que tal modelo seja uma simplificação brutal da história do pensamento científico, o que se quer ressaltar são características muito gerais e não a contingência específica. Dessa forma, tal disjunção, bem como a simplificação, é princípio fundamental de explicação e forma um paradigma geral das ciências que não é formado apenas com elementos "científicos", pois faz parte desse paradigma uma enorme parte imersa, tal como um iceberg, não científica. Assim, mudar um paradigma é mudar pressupostos da própria ciência que fazem parte da forma como se apreende o mundo no dia a dia, ou seja, significa mudar a visão de mundo.

Tais pressupostos de uma visão mecanicista de mundo estão na base da atual crise ambiental. E é por esse motivo que autores como Morin (1999) afirmam que a primazia deve ser dada a uma reforma na forma como se pensa o ser humano e a natureza, pois é necessário reformar a maneira como se entende a problemática ambiental para que se possa agir, não a partir do modus operandi que gerou a crise ambiental, mas de uma forma nova (Morin, 2000). 


\section{A história ambiental e o ensino de História}

Com a crise ambiental que emerge na segunda metade do século XX, há um questionamento da modernidade e da civilização ocidental/globalizada. De tal questionamento surgem a história ambiental e a educação ambiental. Todavia, a institucionalização de ambas, conforme afirma Carvalho (2010a), apesar de tentar romper com a disjunção história-cultura versus natureza e sujeito versus objeto, em parte reproduz tais elementos da "visão de mundo" moderna, produzindo uma história ambiental de "penitência" e uma educação ambiental que é mais um "adestramento".

Primeiramente, abordar-se-á a chamada história ambiental. Um de seus teóricos, Donald Worster (1991), afirma que, no início do século XX, a História restringia-se à "política do passado". No decorrer do século, os historiadores duvidaram de que tão poucos homens ocupados com o poder do Estado poderiam ter tal controle sobre o passado e passaram a fazer de toda a sociedade objeto da História.

Agora chega um novo grupo de reformadores, os historiadores ambientais, que insistem em dizer que temos de ir ainda mais fundo, até encontrarmos a própria terra, entendida como um agente e uma presença na história (Worster, 1991, p. 198-199).

Assim, devem ser levados em conta esses outros "sujeitos da história", os "elementos naturais", que têm a capacidade de condicionar, significativamente, a sociedade. Não mais se busca explicar os fatos sociais exclusivamente pelos fatos sociais, como fazia Durkheim, não mais explicar a sociedade pela sociedade e a "natureza" pela "natureza”, mas se procura entender a interaçáo entre ambas, que gera a sociedade e a "natureza", tal como se conhece, unindo, dessa forma, o que jamais esteve separado, salvo nas análises humanas (Drummond, 1991).

Logo, a história ambiental estuda a interação sociedade-natureza no tempo. O estudo de tal interação, por parte dos historiadores, não é novidade. Basta lembrar a aproximação da História com a Geografia de Vidal de La Blache (1845-1918), feita por Marc Bloch (1886-1944) e Lucien Febvre (1878-1956), na França, ainda na primeira metade do século XX. Todavia, o conceito de história ambiental é uma invenção estadunidense da 
década de 1970, e surgiu como parte da preocupação com o meio ambiente, emergindo a partir do novo movimento ambiental (Worster, 1991, p. 199). A questão ambiental atual fez com que historiadores elaborassem novas perguntas para o passado, sobre a relação sociedade-natureza. Como já se afirmou: cada geração deve reescrever "toda a história", não porque a geração anterior tenha sido incompetente para produzir "sua história", mas porque cada geração deve escrever a "sua história". Hoje, a história ambiental está institucionalizada em todo o mundo, havendo, inclusive, uma Associação Latino-Americana e Caribenha de História Ambiental (SOLCHA).

No Brasil, foi na década de 1980 que os primeiros trabalhos pioneiros de historiadores se abrigaram sob tal denominação ou, pelo menos, abordaram explicitamente a história, a partir da crise ambiental contemporânea. Em 1990, Arthur Soffiati, pioneiramente, reivindicava que os livros didáticos de História deveriam enfocar, criticamente, a relação das sociedades humanas com o ambiente nos seus aspectos materiais e simbólicos. Afirmava o autor que já havia fontes e produção bibliográfica suficientes para ir mais longe e incluir a natureza na história, e que os livros didáticos brasileiros haviam superado uma história factual e voluntarista, dos grandes heróis, passando para uma história social, mas tal não incluía, ainda, o ambiente natural. Um verso de Carlos Drummond de Andrade, citado por Soffiati (1990), expressa, de forma poética, a sua argumentaçáo lógica: "Mesmo produzindo rugidos, a natureza é a grande muda". Caberia aos historiadores produzir uma História em que a natureza não estivesse muda. Mais de 20 anos depois, o apelo de Soffiati parece não ter sido ouvido (Bittencourt, 2003, p. 51). Os poucos livros didáticos que incluem elementos de educação ambiental em suas páginas, em geral, o fazem para cumprir requisitos para receber uma melhor avaliação nos mecanismos de ranqueamento dos livros didáticos, sendo os elementos "ambientais" introduzidos de forma pontual (Soares; Novicki, 2006). Ainda se está muito longe de ter materiais didáticos de História com uma perspectiva ambiental (Almeida; Colacios, 2011).

Apesar do vertiginoso aumento da produção de história ambiental no Brasil, tal perspectiva ainda pouco aparece nas salas de aula, mesmo na formaçáo inicial dos professores de História.

Quanto ao ensino básico, Circe Bittencourt (2003, p. 59) afirma que faltam métodos para introduzir a educação ambiental nas aulas de História, obviamente de forma integrada com as outras disciplinas, como preconizam 
os Parâmetros Curriculares Nacionais. Um esforço tem sido feito nesse sentido, ao se propor que os professores de História devam aprender a sair da sala de aula e "usar os pés" em suas aulas (Arruda, 2008), apontando várias táticas de abordar temas ambientais na disciplina (Gerhardt; Nodari, 2010) ou efetuado uma crítica visando a reformular, ambientalmente, os livros didáticos da área (Almeida; Colacios, 2011).

Apesar da existência de uma historiografia produzida na perspectiva ambiental ser importante para melhorar a participação da disciplina História na educação ambiental, fazer educação ambiental não se reduz a transmitir o saber produzido alhures. Afinal, os professores de História do ensino básico, antes de serem transmissores do conhecimento acadêmico, são produtores de um saber escolar, a partir da apropriação do saber acadêmico.

Ademais, muitas vezes, o saber acadêmico traz grandes dificuldades para a realização da educação ambiental (Carvalho, 2011). É um equívoco a ideia de que o ser humano é naturalmente um destruidor da natureza (Leff, 2005), assim como a de que algumas sociedades vivem em harmonia com ela. Por mais que algumas tenham desenvolvido modos de vida extremamente resilientes, é um equívoco achar que sociedades, como as ditas sociedades simples, têm, necessariamente, um equilíbrio com seu meio (Dean, 1996). Algumas sociedades conseguiram produzir dinâmicas que lhes permitiram conviver longamente em um ambiente, outras conseguiram colocar todo o planeta Terra em risco de colapso.

A história ambiental, em especial a estadunidense, na ânsia de incorporar a natureza na história, acabou, por muitas vezes, não se afastando dos pressupostos e da visão disjuntiva que formam a relação moderna com a natureza. Schama já criticou a história ambiental norte-americana ao afirmar que:

[...] embora a história do ambiente seja uma das mais originais e instigantes que estão sendo escritas hoje, ela, inevitavelmente, expóe o mesmo quadro desanimador: terras tomadas, exploradas, exauridas; culturas tradicionais que sempre viveram numa relação de sagrada reverência com o solo e foram desalojadas pelo individualista displicente, pelo agressor capitalista (Schama, 1996, p. 23).

Tal história tem um tom de "penitência” (Schama, 1996, p. 23), pois enfatiza o processo de destruição da natureza e tende a silenciar a respeito 
das diferentes racionalidades presentes nas relaçôes entre seres humanos e ambiente(s).

Assim, muitas vezes, quando a natureza é incorporada na historiografia ou em materiais para a educação ambiental, parte-se de uma concepção de natureza como algo ainda separado dos seres humanos. A natureza é tratada como um vestígio do Éden original, a partir do qual as açóes humanas são entendidas como intervençóes destrutivas (Diegues, 1998). O ser humano é pensado como um Homo devastans e a história do Brasil é reduzida a 500 anos de destruição da natureza por homens gananciosos e perdulários. Tal perspectiva esquece as diferentes racionalidades que orientaram os seres humanos em suas relaçóes entre si e com o ambiente e apaga os saberes produzidos por grupos como os seringueiros da Amazônia, que desenvolveram formas mais sustentáveis de viver (Carvalho, 2011).

No Brasil, o livro de Warren Dean (1996) é o melhor exemplo dessa problemática. Movido pelas preocupaçóes ambientais contemporâneas, Dean abarcou o desafio de fazer uma história das florestas, produzindo uma narrativa de como a Mata Atlântica brasileira, com cerca de um milhão de quilômetros quadrados, ao longo de "dez mil anos de ocupação humana”, chegou à atual situação, com a pequena porçáo da floresta ainda existente formando um dos ecossistemas mais ameaçados do Brasil. Todavia, tal obra não se constituiu em um modelo de história ambiental das florestas. Sua abordagem foi fortemente criticada por homogeneizar a história das florestas, pois é como se partisse da "perspectiva da floresta”, diante da qual toda intervenção humana seria negativa, não percebendo as descontinuidades que formam a história da relação das sociedades humanas com o bioma da Mata Atlântica (Carvalho, 2005). Esse autor reforça, assim, a dicotomia cultural versus natural, em um tipo de história ambiental que Enrique Leff (2005) denomina como "história ecológica":

Nesta visão não se consegue conceber a complexidade ambiental, como um processo enraizado em formas de racionalidade e de identidade cultural que, como princípios de organizaçáo social, definem as relaçóes de toda sociedade com a natureza; a história ambiental se limitaria a estudar as formas como diversos modos de produção, formaçôes sociais e estruturas de classe se apropriam, transformam e destroem os recursos do seu entorno (Leff, 2005, p. 13). 
Leff (2005) afirma que o elemento que falta nessa "história ecológica" é o tempo. Esses historiadores ambientais ou ecológicos teriam ignorado o tempo, narravam a história da relação entre sociedades humanas e seus ambientes como um continuum temporal, sem cortes, sem diferença. E, em contraposição, Leff propóem que a história ambiental deveria ser uma hermenêutica do ser.

Ora, a educação ambiental, que parte de tal tom de "penitência", tende a fechar os horizontes em uma crítica a uma sociedade crematística, que não foge da própria lógica do que pretende criticar. Perceber diferentes racionalidades no passado e no presente abre o futuro para outras racionalidades possíveis, para outras relaçóes com o mundo natural, para a construção de uma racionalidade ambiental (Leff, 2006).

Nessa perspectiva, é necessário historicizar a natureza para naturalizar a história. Ou, dito de outra forma, a questão ambiental não é uma questão natural, restrita ao funcionamento dos ecossistemas; são os elementos sociais, do modo de vida, das práticas, valores e representaçóes que informam a relaçáo dos seres humanos com o mundo natural, que construíram a perigosa relação hegemônica que a sociedade globalizada tem com o mundo natural. Náo se trata de defender uma postura construtivista radical, mas de partir desse elemento para, entáo, buscar perceber a natureza como uma presença e um agente na história.

Em tal perspectiva, não cabe afirmar que se deve incluir a natureza na história sem questionar que a natureza sempre esteve lá. Para caminhar em direção da superação da disjunção cultura-história versus natureza, deve-se admitir que a afirmaçáo de que é necessário introduzir a natureza na história, apesar de correta em uma dada perspectiva, parte do princípio da disjunção de ambas. Tal interpretação acompanha a lógica do poder que pretende determinar, até mesmo, a forma de se opor a ele (Revel, 1998). Há trabalhos que apontam para o quanto a natureza esteve presente na historiografia (Duarte, 2005), mas, no caso do ensino de História, em geral, toma-se a memória como a história da relação entre história e natureza. Esta pesquisa visa justamente a tomar as memórias da relação história e natureza em sala de aula, não como se fossem a história, mas para interpretá-las como matéria-prima para a construção da história de tal relação. 


\section{O "adestramento" ambiental}

Houve um esforço para que a questão ambiental penetrasse nos muros escolares. A educação ambiental é uma reação à crise ambiental atual. A Conferência Internacional, fomentada pela Organizaçáo das Naçóes Unidas (ONU), em Tbilisi, 1977, já estabelecia, em seus princípios, que a educação ambiental não era repassar informaçóes sobre o ecossistema e seu funcionamento, mas deveria ser um questionamento ético e político, ao que se prefere chamar de racionalidade moderna, ao domínio da natureza e à ampliação ad infinitum do consumo. A partir de Tbilisi, com pressóes internas e externas do movimento ambiental, entre outros fatores, foi construído um aparato institucional para viabilizar a educação ambiental no Brasil, a exemplo da maioria dos países no mundo. Não é necessário, aqui, descrever tal aparato institucional (Gerhardt; Nodari, 2010), apenas constatar que, apesar dele, a experiência em educação ambiental ainda é precária e nova no Brasil.

Há pelo menos três ordens de fatores que levam a pouca expressividade da educação ambiental nas escolas brasileiras: a) a "questão ambiental" é tratada como mais um entre outros "problemas" a serem "solucionados" pela escola, o que retira a dimensão sistêmica da problemática ambiental contemporânea e superestima a capacidade da escola de resolver problemas que são mais amplos que seu âmbito de atuaçáo; b) a crônica carência material e de condiçóes de trabalho, em especial nas escolas públicas - baixos salários e salas superlotadas que dificultam, em muito, por exemplo, um trabalho interdisciplinar nas escolas; e c) a estrutura fragmentada do conhecimento moderno, voltado para o controle e náo para o diálogo com a natureza, que é reproduzido nas escolas.

Os professores de História, além dos problemas práticos de aplicação dos temas transversais em sala de aula, têm aí uma dificuldade extra, pois o pensamento Ocidental separa fortemente a sociedade e a natureza. Por exemplo: entregue uma câmera fotográfica para um estudante e peça para ele fotografar a "natureza". A tendência será fotografar plantas e animais silvestres, o ser humano fica separado da natureza. Sendo a História uma disciplina voltada para o ser humano no tempo, aparentemente, o mundo natural estaria fora de seu escopo. 
Em tal perspectiva reducionista e disjuntiva, a educação ambiental seria um tema para as áreas de Geografia e Biologia, de forma que não é coincidência que são os professores dessas disciplinas que organizam, prioritariamente, os trabalhos de educação ambiental nas escolas, e que são tais disciplinas que hoje formam os paradigmas transdisciplinares, que colonizam os estudos das relaçóes sociedade-natureza (Leff, 2005, p. 14).

A inclusão do meio ambiente como tema transversal nos Parâmetros Curriculares Nacionais pode ser entendida, em tal perspectiva reducionista, como um novo conjunto de informaçóes que devem ser "repassadas" aos alunos. Mas é uma ilusão pensar que apenas informaçóes descontextualizadas alteram o comportamento destes. Para além de repassar informaçóes, o trabalho com tal tema em sala é uma oportunidade de construção de novos valores e um incentivo à produçáo de modos de vida e racionalidades que sejam mais sustentáveis. Daí a necessidade de participação de todas as áreas de conhecimento, levando a uma reflexão sobre a inserção de professores e alunos no(s) ambiente(s) (Vieira, 2002).

As entrevistas realizadas mostram que, entre os professores de História, há uma representação disjuntiva de natureza: quando perguntado a uma professora o que a marcou nas atividades sobre educaçáo ambiental de que participou, ela respondeu que "tudo relacionado ao ambiente para nós agora é importante [...]. Cortaram a árvore aqui, agora ela já cresceu. Para nós foi um escândalo aqui, né?” (Souza, 2009). A preocupação ambiental é identificada como algo exterior à vida humana: uma árvore no pátio interno da escola, o que é um exemplo típico da hegemônica sensibilidade moderna dissociativa, que, justamente, se preocupa com e valoriza positivamente elementos do mundo natural isolados e/ou distantes. Uma sensibilidade de "ursinho de pelúcia", que positiva os elementos naturais, quando eles estão controlados/“domesticados” ou destruídos (Thomas, 1988, p. 356-357). Dessa forma, apesar de, nas últimas décadas, o estado do Mato Grosso ser um dos que mais devastou as florestas no Brasil, a preocupação com a natureza ainda apresenta traços gerais de uma sociedade urbana que valoriza, positivamente, símbolos de uma Arcádia perdida, enquanto na prática ampliam a destruição das áreas florestais.

Tal concepção preservacionista, em princípio, não é incompatível com uma posiçáo conservacionista, mas, igualmente, disjuntiva. E aqui é utilizada uma classificação própria do movimento ambiental e convém 
ressaltar que, segundo McCormick (1992), há três correntes do movimento. As duas primeiras têm origem no século XIX: o preservacionismo, em que "a proteção da natureza havia sido uma cruzada moral centrada no ambiente não humano", e, em geral, acreditava-se que a natureza deveria ser mantida "intocada” em alguns lugares de excepcional beleza para deleite e recuperação espiritual do homem moderno no contato com esse mítico paraíso terrestre; e o "Conservacionismo, um movimento utilitário centrado na administração racional [ou melhor na racionalização] dos recursos naturais". Esse movimento pretendia a conservação, a partir da utilidade futura dos recursos e de sua otimização. E a terceira corrente é o Novo Movimento Ambiental, que surgiu na década de 1960, com a crise ambiental global, preocupando-se com a sobrevivência da própria espécie humana (McCormick, 1992, p. 63-64). Todavia, trata-se de tipos ideais. $\mathrm{Na}$ prática, há uma variedade e mescla muito grande de posiçôes, de forma que as três aparecem nas falas dos professores entrevistados. Assim, a natureza compreendida como um recurso a ser otimizado em sua utilização emerge, em alguns momentos, em suas falas :

A natureza hoje em dia ela é principalmente a questão dos recursos naturais, placas tectônicas, é origem da vida, não é? Teoria da criação, teoria da evolução, eu acredito que hoje em dia está tendo mais visão com relação a isso, porque é preciso que se fale realmente na questão da natureza, eu falo para os alunos, por exemplo, gosto muito de trabalhar a questão do mapa-múndi político com eles [...] a questão dos continentes, [...] de separação de um continente para outro, as proporçóes de água que existem, os oceanos, os mares, eu acho que neste momento a gente está mais focado nisso, em trabalhar a questão das relaçóes [...] (Silva, 2010).

Tal excerto parece expressar a prática que Brüger (2004) denomina “adestramento ambiental". A educação ambiental é entendida, primeiramente, como o repasse de informaçóes sobre o funcionamento dos ecossistemas. Compreendida dessa forma, náo caberia realmente muito espaço para a atuação dos professores de História. A educaçáo ambiental seria algo de competência dos professores de Biologia e Geografia, pois caberiam à História os aspectos "sociais e políticos", os quais são entendidos em desconexão com o mundo natural, mesmo que haja uma tentativa de "trabalhar a questão das relaçôes”. 
Tal representação disjuntiva é expressa ainda nas ausências. Quando perguntado aos entrevistados como trabalhavam temas em sala de aula sobre a industrialização, por exemplo, em geral, as narrativas se desenvolviam como se o ser humano atuasse em um palco vazio; a natureza pouco apareceu nas narrativas. A fragmentação história/cultura versus natureza aparece, também, quando se pergunta sobre as atividades voltadas para a educaçáo ambiental nos estabelecimentos de ensino em que trabalham. Dessa forma, uma entrevistada afirma sobre atividades de educação ambiental:

Muitas, mas muitas mesmo, inclusive têm aulas de ciências mesmo, aulas, projetos, o terceiro bimestre é todo voltado para ciência e o meio ambiente, tudo para o meio ambiente, não só a Biologia, a Química, a Geografia, entendeu? Eles fazem trabalhos com os alunos, eles fazem amostras mesmo, né? Mostrando os efeitos e inclusive com experiências, eles fazem experiências [...], os alunos dão show, entendeu? Lá na escola, você sabe que tem laboratório, então têm biólogos, químicos [...]. Então são trabalhados esses temas ambientais (Freire, 2010).

A educação ambiental aparece como algo realizado por "eles", os professores das ciências naturais. Apesar da tentativa de realização de um trabalho interdisciplinar nas escolas, ainda aparece, fortemente, nas entrevistas realizadas, uma representação disjuntiva que atrapalha o entendimento dos problemas ambientais e da crise pela qual se passa.

\section{Memória: homogeneização e silenciamento}

Em geral, os professores não têm um "discurso pronto" sobre educação ambiental, com isso fica mais evidente que, ao falar, é mobilizado todo o "caldo de cultura" destes (assim como ocorre em todo processo comunicativo), em elementos que nem sempre têm uma total coerência. Porém, indicam um processo de transformação nas representaçóes ao incorporarem, da sua forma, o "discurso verde", ou seja, ao indicarem a forma como participam da "ecologização" da sociedade.

Deve ficar claro que "ecologização", aqui, não implica, necessariamente, a adoçáo de um modo de vida que leve a um ecodesenvolvimento, 
mas apenas uma mudança de postura, na qual a natureza deixa de ser percebida, em geral, como uma fonte inesgotável de recursos para ser reconhecida como um "problema” que inspira cuidados, o que dá uma conotação positiva, em geral, para o que se identifica como "ecologicamente correto". Ou seja, a "ecologização" é a construção social da questão ambiental (Hannigan, 2009), que pode ou não levar à produção e à hegemonia de uma racionalidade ambiental (Leff, 2006). Barbosa (1991), em um artigo que busca mapear a penetração, a importância e o significado da problemática ambiental no seio da sociedade brasileira, afirma que, pelo menos, a partir do início da década de 1990, "O meio ambiente se tornou o grande referencial para todos os grupos. Do ponto de vista político, a adaptação ao tema ecológico, ainda que de forma superficial, apresenta-se como a única saída competitiva” (Barbosa, 1991, p. 242). No caso das entrevistas em tela, nas trajetórias de vida dos(as) professores(as) de História, a virada na "ecologização" é situada na década de 1990. Assim, os entrevistados situam um período antes e um período depois da emergência do "meio ambiente". Em relação ao período anterior, uma entrevistada afirma sobre suas aulas de História: "Sinceramente, a gente não tinha essas discussões de natureza não, geralzão, não tinha específico [...] A gente ficava mais na discussão política, social, não tinha [...]" (Souza, 2009). Tal constatação, corroborada em outras entrevistas, indica que o que acontece é um processo de homogeneização de dois períodos, para professores atuantes na rede pública de Cuiabá, tendo como marco a década de 1990. Não é incomum um evento marcante ou a emergência de algo novo gerar um processo de homogeneização na memória social (Fentresss; Wickham, 1992, p. 120).

Outra entrevistada foi enfática ao ser perguntada como a natureza aparecia nas suas aulas quando iniciou a lecionar; afirmou que "não aparecia". E a mesma entrevistada afirma sobre como hoje aparece: "em tudo", e afirma ainda que "a gente hoje incorpora essa coisa de ambiente" (Soares, 2010). A natureza, que antes não estava presente, quando emerge a "questão ambiental" - e a natureza passa a ser representada a partir das categorias ambientais —, passa a estar presente em “tudo”. O que há, aqui, é um silenciamento sobre diferentes representaçóes de natureza que "antes" estavam presentes nas práticas, como, talvez, a natureza como elemento de orgulho nacional ou como fonte inesgotável de matéria-prima, hipótese corroborada por um 
professor aposentado quando afirma que, no final da década de 1970 e início da de 1980, quando iniciou sua atividade docente:

A impressão que se tinha era que nós vivíamos num paraíso ainda intocável, era um Estado coberto por áreas verdes, com a presença dos biomas do Cerrado, da floresta amazônica, do Pantanal e isso parecia que era um santuário inesgotável, indestrutível, não havia ainda a presença do agronegócio, a destruição do portal da Amazônia [Cuiabá-Mato Grosso], começávamos ainda a viver as primeiras experiências [...] do Polo Noroeste, [...] foi um projeto [...], desenvolver a agricultura no cerrado mato-grossense e, ainda, era uma visão dominante na sociedade mato-grossense de que o Cerrado era improdutivo. A primeira experiência de produção em larga escala, veio [...] e era muito difícil a gente prever que ali começava um processo de destruiçáa do Cerrado mato-grossense, que hoje foi consolidado pelo agronegócio, lamentavelmente a gente está vivendo um processo de destruiçáo deste Cerrado, comprometendo todo o equilíbrio do ambiente deste Estado, comprometendo a própria sobrevivência do Pantanal e da Floresta Amazônica Na realidade não existia essa consciência da necessidade, naquele momento, de começar a discutir um projeto de desenvolvimento sustentável no Estado, não se tinha essa visão ainda, era muito cedo ainda para esse tipo de discussão, justamente porque era tudo tão pujante, que parecia que aquilo tudo era indestrutível (Cunha, 2010).

A ideia de uma natureza cornucópica, muitas vezes, não estava assentada na abundância do mundo natural, mas na crença da capacidade tecnocientífica de resolver todos os problemas (Carvalho, 2010b). De qualquer forma, o excerto que destaca o mito do progresso e uma representação da natureza como um grande celeiro a ser explorado pelo ser humano vai ao encontro do material didático para a área de História disponível na época.

Partindo desse quadro, uma entrevistada, já aposentada, afirma diante da pergunta como aparecia a natureza em suas aulas de História: "Não aparecia, a natureza não aparecia nas aulas, não tinha natureza." (Corvoisier, 2010). O que deve ficar claro é que não aparecia a natureza "ecologizada", a partir, entre outros, do debate sobre educação ambiental, que emergiu no sistema de ensino público na década de 1980. Mas outras naturezas estavam presentes nas aulas de História. A emergência da "ecologização" silencia essas outras naturezas, mas teve/tem de lidar com elas. 


\section{Educação ambiental}

Volta-se, então, com essa nova ótica para as entrevistas aqui analisadas. Uma entrevistada, ao ser questionada sobre a função da educação ambiental, afirma categoricamente que:

Não só preservar, né? Que é o chavão, mas é a nossa própria existência depende dessa Educação Ambiental, como a gente deve se relacionar com o ambiente, com os próprios alunos, como preservar mesmo, que é para o futuro nem nosso, mais para o futuro deles [...] (Souza, 2009).

A depoente mostra claramente uma solidariedade transgeracional e entende a "questão ambiental" como um problema que une a espécie humana e na qual a existência humana e os modos de vida é que estáo em jogo. Dessa forma, os mesmos entrevistados se afastam de uma representação disjuntiva de natureza. A preocupação com a abordagem interdisciplinar, presente em todas as falas dos professores em atividade, mesmo que acompanhada das dificuldades de sua realização prática, é outro indício de uma concepção complexa de educação ambiental. Tal complexidade pode ser percebida na narrativa de outra entrevistada, quando questionada sobre onde aparece a natureza em suas aulas:

[...] É uma relação muito próxima, então não tem como você trabalhar uma questão histórica sem deixar de ver nesta questão também a questão ambiental [...]. Então não tem como você dissociar, você trabalha de uma forma, talvez até inconsciente, mas é tão inerente [...]. Até porque, conservar hoje, existe uma conscientização muito maior, né? Em relação às questóes ambientais. Então parece que isso, a gente incorpora, né? [...]. O homem hoje ele é muito mais consciente de que ele precisa desse ambiente, de que ele transforma, de que ele tem necessidade de transformar esse ambiente, mas já há uma preocupação na questão da sustentabilidade, né? [...] E nós, enquanto educadores, também devemos ter essa preocupação para as nossas salas de aula, para os nossos alunos, fazer com que eles entendam que eles é que gozam do privilégio desse ambiente e que nós vamos ter o ambiente que nós quisermos da forma que nós quisermos (Soares, 2010).

A responsabilidade ética do ser humano sobre o seu próprio futuro enquanto espécie é algo presente na retórica ambiental dos professores, gerando 
um questionamento sobre os valores e o modo de vida hegemônico. Todavia, esse questionamento é datado na trajetória de vida dos professores, como já se argumentou. Assim, uma entrevistada responde sobre como aparecia a natureza quando iniciou a lecionar:

[...] Não tinha isso [natureza], sinceramente eu só vim a me preocupar com isso quando eu vim aqui para o Liceu [na década de 1990] e eu achei os parceiros que tinham essa preocupação de levar para o aluno, fazer discussão, aí eu me interessei, me interesso agora [...], mas antes não tinha essa, eu também confesso que não tinha [...] (Souza, 2009).

A introdução da educação ambiental nas escolas e, de uma forma geral, o processo que aqui é denominado "ecologização" são eventos que marcam o período do "antes", quando não se falava de natureza, pois à História cabia versar sobre os aspectos "sociais e políticos", em uma perspectiva disjuntiva, e o "agora", no qual a natureza é tratada como um problema a ser trabalhado de forma interdisciplinar e complexa. Mas não se pode pensar o processo de transformaçôes das representaçôes a partir de tal homogeneização da memória social.

Dessa forma, o que se procurou em tais falas não foi a homogeneidade dos símbolos e sinais públicos, mas, sim, a multiplicidade das representaçóes sociais em embate, pois entender tal dinâmica de conflitos é uma forma de entender a processualidade das representaçóes, e em tal processualidade, talvez seja possível perceber melhor as "artes de fazer" dos sujeitos estudados, desfazendo a aparente contradição de professores que apresentam elementos tanto de uma representação disjuntiva como de uma representação complexa de natureza. Não há uma diferenciação de posições entre professores com maior ou menor grau de formação, ou em colégios "centrais" e "periféricos"; mesmo que a amostra não tenha sido estatisticamente construída, isso indica que se trata, antes de tudo, de um processo de transformação nas representaçóes que não é linear, por mais que a própria memória social estabeleça uma homogeneização, uma linearidade.

Assim, o que aparece, em um primeiro momento, como contradiçóes na fala dos depoentes, é um importante indício para entender o processo de transformação das representaçóes, tanto no que tange à persistência de uma perspectiva disjuntiva quanto no que se refere à emergência de uma 
abordagem mais complexa da relação com a natureza. Ademais, seja no momento "anterior" ou "posterior" à "ecologização", os professores produzem um "currículo oculto", a partir do qual trabalham com temas e questóes colocadas por suas experiências.

Algumas experiências são, hoje, reelaboradas na memória, como símbolo da degradação ambiental e da "questão ambiental":

[...] tem outra frase que diz assim "é preciso pensar um pouco naqueles que ainda vêm, nos filhos e nos filhos dos nossos filhos", então em que planeta eles vão viver? Não é mesmo? Eu tomava banho no rio Cuiabá, maravilha, delícia, pulava daquelas pedras, agora eu vou lá naquele lugar, é só lixo, meu pai quantas vezes ele ia lá, no final da tarde a gente não tinha carne para comer, ele ia lá e pegava bagre, piraputanga e vinha, limpava e fazia, hoje vai lá, você não vai achar [...] (Freire, 2010).

Mas, mesmo considerando essas reelaboraçóes "ambientais" das experiências passadas, a atenção à narrativa das experiências cotidianas traz ao primeiro plano o lugar enquanto espaço de vivência (Santos, 2002). E a atenção para o lugar pode conduzir os professores a introduzir a problemática ambiental em suas aulas. Uma entrevistada, quando foi perguntada sobre como aparecia a natureza nas suas aulas de História, no início de sua carreira docente, em 1985, em uma cidade, então, de garimpo, Poxoréu, afirmou:

[...] Não vou dizer pra você que lá em oitenta e oito, em oitenta e nove, não, não é bem assim, mas a gente sempre falou sobre a questão da natureza, quando eu trabalhei em Poxoréu, a gente trabalhava muito com uma música, né? Que fala da cidade e conta das belezas da natureza de lá e fala assim: "esses versos que eu canto aqui distante eu quero enaltecer, capital do diamante a minha terra que me viu nascer", aí fala assim: "quero banhar na lagoa", que tem uma lagoa linda, "quero escalar o morro", porque lá tem um morro lindo que chama Morro da Mesa [...]. Mas na verdade era uma utopia, porque não tinha mais condiçóes, porque a lagoa era suja, poluída, a cidade era um buraco, todo mundo queria mais ir embora e ainda tinha pessoas que falavam assim: "tem que ir embora antes que acabe", e tudo mais porque é um buraco. O garimpo destruiu tudo, o homem destruiu, a ganância e tudo mais, então não tinha como, vamos dizer que não falava de natureza, a natureza está ligada [...]. 
Em Poxoréu, a gente cantava, falava e apresentava, né? E como era lindo, [...] então a gente trabalhava essa questão, aí o que vai dar sustento para essa populaçáo, para a vida dessas pessoas, que moram ali e não querem sair dali, porque amam aquele lugar, [...] Acho que eu nunca deixei de trabalhar essas questóes assim, que são questóes de vida [...] o homem não vive sem a natureza [...] (Freire, 2010).

A prática de uma história-problema inspirada a partir das problemáticas locais leva a professora a buscar as conexôes, a prática de uma educação ambiental. Assim, partindo de uma identidade local, a natureza pode ser entendida como marcada por uma ética transtemporal e translocal e que implica uma transapropriação, ou seja, para além daqueles que queriam apenas "feitorizar" uma riqueza facial ao alcance da mão e depois "ir embora antes que acabe"; havia uma identificação com o lugar, para além da propriedade e da apropriação individual, daqueles que "amam aquele lugar", pensando, também, nas futuras geraçóes.

Outro exemplo é dado no depoimento de um entrevistado, já aposentado, que no início da década de 1980, com o vertiginoso processo de expansão populacional de Cuiabá, relatou os problemas socioambientais da cidade e suas implicaçóes em sala de aula, mas isso ocorria desde que o professor estivesse aberto e atento para trabalhar a partir do local, assim fazendo a conexão com outras escalas:

[...] o São João Del Rei que é um dos maiores bairros de Cuiabá, e era uma regiáo ocupada por cerrado... e a condição de vida daquele povo, a destruição do cerrado para o surgimento de grandes bairros populares, comunidades morando às margens dos córregos. Isso tudo acaba despertando em você a necessidade de discutir essa realidade em sala de aula com seus alunos, porque muitos desses alunos provêm dessa realidade, alunos que vivem nesses bairros periféricos, esses bairros carentes, então não tem como você fugir dessa discussão, discutir a história de sua cidade, a história do seu país. (Cunha, 2010).

\section{Considerações finais}

Em princípio, este trabalho corrobora o resultado de outros que estudam as representaçóes de natureza de professores, pois estes apresentam 
uma representação disjuntiva: história/cultura versus natureza, sujeito versus objeto, indicando o quão importante é uma efetiva introdução da educação ambiental na formação inicial dos professores, o que já está previsto na Política Nacional de Educação Ambiental desde 1999. Mas isso ainda está muito distante de ser realizado, em especial em cursos como o de História.

Todavia, há também presente na narrativa das memórias dos professores a representação de práticas educacionais que vão além de um "adestramento ambiental”. A complexidade dessas práticas de educação ambiental, nas quais há uma tentativa, mesmo que não sistemática, de superação das disjunçóes e da adoção de uma abordagem mais complexa, indica o quão importante é considerar a memória e as práticas dos professores em projetos de formaçáo continuada, de forma a não reproduzir uma racionalidade burocrático-técnica que, em nome da eficácia produtivista e/ou da conscientização, silencia as experiências do outro como um "não saber". Há que se considerar a trajetória de formação desses professores, não enquanto algo que deve ser eliminado para ser substituído pelo saber acadêmico, mas deve ser reconhecida a riqueza de experiências necessárias para construir uma educação ambiental que não será uma fórmula universal, mas, sim, práticas particulares conectadas, pelo menos essa é a aposta aqui.

\section{Referências}

ALMEIDA, J. P. de; COLACIOS, Roger Domenech. (Org.). Ambiente e Sociedade: trajetos de História, Ecologia Política e Educação Ambiental. Gravataí-RS: Escritos, 2011. E-book. ARRUDA, G. Natureza: uma nova "sala de aula" para o ensino de História. In: OLIVEIRA, M. D. de; CAINELLI, M. R.; OLIVEIRA, A. F. B. de. (Org.). Ensino de História: múltiplos ensinos e múltiplos espaços. Natal: EDFURN, 2008. p. 59-67.

BARBOSA, L. Garimpo e meio ambiente: águas sagradas e águas profanas. Estudos Históricos, Rio de Janeiro, v. 4, n. 8, p. 229-243, 1991.

BITTENCOURT, C. M. F. Meio ambiente e ensino de História. História \& Ensino, Londrina, v. 9, p. 63-96, out. 2003.

BRÜGGER, P. Educação ou adestramento ambiental. 3. ed. rev. e ampl. Florianópolis: Letras Contemporâneas, 2004. 
CARVALHO, E. B. de. Os historiadores e as florestas: dez anos depois de $A$ ferro e fogo. Esboços. Florianópolis, v. 13. p. 107-124, 2005. Disponível em: < http://www.periodicos. ufsc.br/index.phplesbocos/article/view/274/9919 >. Acesso em: 15 abr. 2010.

. História Ambiental e o Ensino de História: uma difícil aproximação. In: FANAIA, J. E. de A.; CEREZER, O. M.; RIBEIRO, R. R. (Org.). Escrita da História. Cáceres: Editora da UNEMAT, 2010a. p. 209-219. E-book

. Por que matar a galinha dos ovos de ouro? A representação da tecnologia para a elite industrial madeireira no Paraná, 1942-1965. In: SIMPÓSIO INTERNACIONAL DE HISTÓRIA: TERRITÓRIOS E FRONTEIRAS \& ENCONTRO REGIONAL DE HISTÓRIA: HISTÓRIA, NATUREZA E FRONTEIRAS, 1., 6., 2010, Cuiabá. Anais eletrônicos. Cuiabá: ANPUH-MT, 2010b. Disponível em: < http://www.encontro2010. mt.anpuh.org/conteudo/view?ID_CONTEUDO=654 >. Acesso em: 18 jan. 2011

. Uma História para o futuro: o desafio da educação ambiental para o ensino de História. Revista História Hoje, v. 5, n. 14, p. 1-10, 2011. Disponível em: < http://www. anpuh.org/arquivoldownload?ID_ARQUIVO=11916 >. Acesso em: 23 jul. 2011

. História, Natureza, Patrimônio e identidade: a Educação Ambiental e os professores de História da Rede Pública de Ensino de Cuiabá. In: PAULA, Zueleide Casagrande de. (Org.). Polifonias do Patrimônio. Londrina: Eduel, 2012. p. 325-347.

CORVOISIER, M. A. G. Maria Antônia Galvão Corvoisier: depoimento. Entrevistador: Ely Bergo de Carvalho. [17 diz. 2010], Cuiabá, 2010.

CUNHA, G. R. da. Gilson Romeu da Cunha: depoimento. Entrevistador: Ely Bergo de Carvalho. [nov. 2010]. Cuiabá, 2010.

DEAN, W. A ferro e fogo: a história e a devastação da Mata Atlântica brasileira. São Paulo: Companhia das Letras, 1996.

DIEGUES, A. C. S. O mito moderno da natureza intocada. 2. ed. São Paulo: HUCITET, 1998.

DRUMMOND, J. A. A história ambiental: temas, fontes e linhas de pesquisa. Estudos Históricos, Rio de Janeiro, v. 4, n. 8, p. 177-197, 1991.

DUARTE, R. H. História \& Natureza. Belo Horizonte: Autêntica, 2005.

FENTRESS, J.; WICKHAM, C. Memória Social: novas perspectivas sobre o passado. Lisboa: Teorema, 1992.

FREIRE, K. M. da C. Kátia Maria da Costa Freire: depoimento. Entrevistador: Ely Bergo de Carvalho. [7 jun. 2010]. Cuiabá, 2010.

GERHARDT, M.; NODARI, E. S. Aproximaçôes entre História Ambiental, Ensino de História e Educação Ambiental. In: BARROSO, V. L. M.; et. al. Ensino de História: desafios contemporâneos. Porto Alegre: EST, 2010. p. 57-72. 
GRÜN, M. Ética e Educação Ambiental: a conexão necessária. 3. ed. Campinas: Papirus, 1996.

HANNIGAN, J. Sociologia ambiental. Rio de Janeiro: Vozes, 2009.

LEFF, E. Construindo a História Ambiental da América Latina. Esboços, Florianópolis, v. 13, p. 11-30, 2005.

- Racionalidade ambiental: a reapropriação social da natureza. Rio de Janeiro:

Civilizaçáo Brasileira, 2006.

McCORMICK, J. Rumo ao Paraíso: a história do movimento ambientalista. Rio de Janeiro: Relume-Dumará, 1992.

MORIN, E. Ciência com Consciência. 3. ed. Rio de Janeiro: Bertrand Brasil, 1999. . Os Sete Saberes necessários à Educação do Futuro. 2. ed. São Paulo: Cortez, 2000.

REIGOTA, M. Meio ambiente e representação social. São Paulo: Cortez, 1995.

REVEL, J. Microanálise e construção do social. In: experiência da microanálise. Rio de Janeiro: FGV, 1998. p. 15-38.

SANTOS, J. J. M. dos. História do lugar: um método de ensino e pesquisa para as escolas de nível médio e fundamental. História, Ciência, Saúde - Manguinhos. Rio de Janeiro, v. 9, n. 1, p. 105-124, jan./abr. 2002.

SCHAMA, S. Paisagem e Memória. São Paulo: Companhia das Letras, 1996.

SILVA, G. D. Gonzalo Dias Silva: depoimento. Entrevistador: Rafael Marcos de Souza Fernandes. [5 mar. 2010], Cuiabá, 2010.

SOARES, A. de A R.; NOVICKI, V. Educação ambiental através de livros didáticos de história do segundo segmento do ensino fundamental. In: ENCONTRO ANUAL DA ASSOCIAÇÃO NACIONAL DE PÓS-GRADUAÇÃO E PESQUISA EM EDUCAÇÃO, 29., 2006, Caxambu. Anais... Caxambu: ANPED, 2006.

SOARES, M. do S. Maria do Socorro Soares: depoimento. Entrevistador: Rafael Marcos de Souza Fernandes. [5 mar. 2010], Cuiabá, 2010.

SOFFIATI, A. A Ausência da Natureza nos Livros Didáticos de História. Revista Brasileira de História, São Paulo, v. 9, n. 19, p. 43-56, set.1985/fev.1990.

SOUZA, C. N. Cláudia Noêmia Souza: depoimento. Entrevistador: Ely Bergo de Carvalho. [7 dez. 2009]. Cuiabá, 2009.

THOMAS, K. O homem e o mundo natural: mudanças de atitudes em relação às plantas e aos animais (1500-1800). São Paulo: Companhia das Letras, 1988. 
VIEIRA, P. F. Repensando a Educação para o Ecodesenvolvimento no Brasil. In: ENCONTRO NACIONAL DE ENSINO AGRÍCOLA. Camboriú, 31 out. 2002. (xerox).

WORSTER, D. Para fazer história ambiental. Estudos Históricos, Rio de Janeiro: v. 4, n. 8, p. 198-215, 1991.

Resumo: A introdução da educação ambiental no ensino é um grande desafio. Visando a contribuir com tal propósito, a presente pesquisa busca compreender as representaçóes de natureza que informaram a prática profissional dos professores de História da rede pública de ensino básico de Cuiabá, Mato Grosso, Brasil. Foram entrevistados professores, utilizando a metodologia da história oral, sendo que, ao lado de uma representação disjuntiva, segundo a qual a natureza não estaria nas aulas de História, também há uma representação mais complexa de natureza e de educação ambiental. Tal embate de posiçōes emerge a partir da década de 1990, silenciando outras representaçôes de natureza. A partir desse quadro, são abordadas algumas implicaçôes para o desenvolvimento da educação ambiental.

Palavras-chave: ensino de história, educação ambiental, natureza, representações.

\title{
"Nature did not use to appear in History classes": environmental education lessons learned from History teachers' reminiscences
}

\begin{abstract}
The introduction of Environmental Education in teaching is a great challenge. To contribute to that purpose, this research seeks to understand the representations of nature which informed the professional practice of History teachers from the Public Fundamental Schools in Cuiabá, Mato Grosso, Brazil. The interviews were conducted using the oral history methodology. Being that in addition to a disjunctive representation, according to which nature would not be present in the lessons of history, there is a more complex representation of nature and Environmental Education. Such clash of positions emerges in the 1990s, silencing other representations of nature. Within this framework, some implications for the development of Environmental Education are covered here.
\end{abstract}

Keywords: history teaching, environmental education, nature, representations.

Recebido em: 08/03/2012

Aprovado em: 07/07/2012 